\title{
Tocopherol, selenium and ubiquinone in the turkey and the pigeon
}

\author{
By A. T. DIPLOCK, J. BUNYAN, E. E. EDWIN AND J. GREEN \\ Walton Oaks Experimental Station, Vitamins Ltd, Tadworth, Surrey
}

(Received I4 Fuly 1961)

In previous studies (Edwin, Diplock, Bunyan \& Green, I96I; Green, Diplock, Bunyan \& Edwin, 1961) it was shown that, in both the rat and the rabbit, vitamin $\mathrm{E}$ deficiency led to diminished tissue concentrations of ubiquinone, which could be increased by administration of $\alpha$-tocopherol. In the rat, selenium was found to have a similar effect. We decided to study, therefore, the effect of $\alpha$-tocopherol and Se in avian species, and have now done so for the turkey poult and the pigeon. The young turkey was regarded as a suitable experimental animal, since its rate of growth is high and it is known to be susceptible to vitamin E deficiency during the first few weeks of life (cf. Creech, Feldman, Ferguson, Reid \& Couch, 1957). The pigeon (the adult bird was used) was chosen because of the exceptionally high rates of oxidation known to occur in its powerful pectoral muscles. In a preliminary communication, we have already observed (Bunyan, Edwin, Diplock \& Green, 1961) that the breast muscle of the pigeon contains an unusually high concentration of ubiquinone, as indeed it does of several other co-factors and enzymes concerned with biological oxidations.

\section{EXPERIMENTAL}

Turkeys. Fifty-four Broad Breasted Bronze turkeys of both sexes were obtained as day-old poults from a commercial hatchery and reared in pens on raised wire floors.

Pigeons. Twenty-four young mature fantail pigeons of both sexes were obtained from a commercial supplier and kept in pens on raised floors.

Turkey diets. Diet TDI was a diet low in vitamin $\mathrm{E}$ based on defatted vegetable protein and had the percentage composition: soya-bean meal 55, maize meal 20 , sorghum meal $18 \cdot 5, \mathrm{CaHPO}_{4} \cdot 2 \mathrm{H}_{2} \mathrm{O}_{3}$, ground oyster shell $2.5, \mathrm{NaCl} 0.5$, vitamin mix 0.5. $\mathrm{MnSO}_{4} .4 \mathrm{H}_{2} \mathrm{O}$ (3.5 p.p.m.) was included. The vitamin mix supplied (mg/kg diet): thiamine $4 \cdot 8$, riboflavin $7 \cdot 7$, pyridoxine $7 \cdot 7$, calcium pantothenate $15 \cdot 4$, nicotinic acid I 6 , folic acid I.9, p-aminobenzoic acid I9, inositol 970 , biotin $0 \cdot 2$, choline dihydrogen tartrate 3900 , menaphthone bisulphite 0.48 and cyanocobalamin 0.05 .

Diet $\mathrm{TD}_{2}$ was a diet deficient in vitamin $\mathrm{E}$ and $\mathrm{Se}$ and had the composition: torula yeast (Lake States Yeast and Chemical Division of St Regis Paper Company, Rhinelander, Wisconsin, U.S.A.) 70, glucose 12.6, 'stripped' lard (Distillation Products Industries, Rochester, New York, U.S.A.) 5, mineral mix IO.I, ground oyster shell I, DL-methionine 0.4 , L-arginine 0.4 , vitamin mix 0.5 . The mineral mix supplied (g/kg diet): $\mathrm{CaCO}_{3} 34, \mathrm{CaH}_{4}\left(\mathrm{PO}_{4}\right)_{2} \cdot 2 \mathrm{H}_{2} \mathrm{O}_{46} 6.4, \mathrm{NaCl}_{5}, \mathrm{MnSO}_{4} \cdot 4 \mathrm{H}_{2} \mathrm{O} \mathrm{I}_{1}$, hydrated 
ferric citrate $\mathrm{r} \cdot 6, \mathrm{CuSO}_{4} \cdot{ }_{5} \mathrm{H}_{2} \mathrm{O} 0.02, \mathrm{ZnSO}_{4} 0.014, \mathrm{KI} 0.04, \mathrm{CoCl}_{2} .6 \mathrm{H}_{2} \mathrm{O} 0.0005$, $\mathrm{KCl} 6$ and $\mathrm{MgSO}_{4} \cdot 7 \mathrm{H}_{2} \mathrm{O} 5 \cdot 8$. In addition, each poult received, each week, 4000 i.u. vitamin $A$, 1000 i.u. vitamin $D_{3}$ and $50 \mu \mathrm{g}$ menaphthone as an emulsion in the drinking water.

Pigeon diets. PD I was a diet deficient in vitamin E, based on a diet previously used by Carter \& O'Brien (1937) to produce thiamine deficiency in this species. It had the composition: casein, 'low vitamin content' (Genatosan Ltd) I8, rice starch 62, lard Io, McCollum's salt mix (Edwin, Diplock et al. 1961) 4, agar I and B-vitamin mix (in glucose) 5. The vitamin mix supplied $(\mathrm{mg} / \mathrm{kg}$ diet): thiamine 9, riboflavin 18 , nicotinic acid $9 \circ$, pyridoxine 9 , pantothenic acid go, folic acid 2, cyanocobalamin 0.3 , inositol $90, p$-aminobenzoic acid 90 and choline dihydrogen tartrate 900 . The diet was mixed with water, dried at $100^{\circ}$ for $2 \mathrm{~h}$ and then broken up and given to the birds as granules. Each bird received weekly, emulsified in the drinking water, rooo i.u. vitamin $A, 250$ i.u. vitamin $D_{3}, 12 \mu \mathrm{g}$ menaphthone and (in case heat treatment of the diet had destroyed some of its thiamine) an extra $\mathrm{I} \mathrm{mg}$ thiamine.

Diet $\mathrm{PD}_{2}$ had the composition: torula yeast (as in diet $\mathrm{TD}_{2}$ ) 36, rice starch 49, 'stripped' lard 5, McCollum's salt mix 4, agar I, B-vitamin mix 5, and the same vitamin supply in the drinking water as for PD I. This diet was also given in the form of granules.

Turkey experiment. The day-old poults were randomized into three groups. One group was given diet TD I, a second group the same diet supplemented with $5^{\circ} \mathrm{mg}$ DL- $\alpha$-tocopheryl acetate $/ \mathrm{kg}$ and the third the same diet supplemented with 0.5 p.p.m. of Se (as sodium selenite). During the first 7 days, nineteen poults died, apparently of some bacterial infection. The infection was controlled in the remainder with furazolidone, which was later withdrawn. After 22 days, twenty-four of the surviving birds were divided into three groups of eight. Those that had been fed on diet TD I were transferred to diet $\mathrm{TD} 2$, those that had been fed on diet TD I + vitamin $\mathrm{E}$ now received diet $\mathrm{TD} 2+$ vitamin $\mathrm{E}$ and, similarly, the third group now received diet $\mathrm{TD} 2+$ Se. After a further 23 days on these diets (making 45 days in all) some birds in the control group began to exhibit deficiency signs: one turkey died at $4 \mathrm{I}$ days and one was killed in extremis 2 days later. Post mortem the birds showed haemorrhagic musculature of the back and legs, characteristic of exudative diathesis. On the $45^{\text {th }}$ day, five turkeys from each group were killed by breaking their necks, and heart, liver and samples of breast and thigh muscles were removed. The tissues from each group were pooled for determination of their ubiquinone, ubichromenol and $\alpha$-tocopherol contents. The method was that of Diplock, Green, Edwin \& Bunyan ( 1960 ). Survivors from the group given vitamin $\mathrm{E}$ were then transferred to a commercial turkey ration and reared to 5 months of age, when they were killed, and their hearts, livers and ovaries (they proved all to be female) were removed for analysis.

Pigeon experiment. Since the birds were obtained as mature adults and had been fed on a normal commercial ration, it was expected that some considerable time would be necessary to deplete the control animals of vitamin $\mathrm{E}$ and Se. However, since there is some evidence that Se depletion in the chick is more rapid than tocopherol depletion (Søndergaard, Bieri \& Dam, I960), for the first I 2 weeks of test basal diet PD I, which 
was deficient in vitamin $\mathrm{E}$ but not in Se, was used. The birds were randomized into four groups. Groups $I$ and 2 were fed on the basal diet, group 3 on the diet supplemented with $100 \mathrm{mg} \alpha$-tocopheryl acetate $/ \mathrm{kg}$ and group 4 on the diet supplemented with I p.p.m. of Se (as sodium selenite). In case the heat treatment of the diet had destroyed some tocopherol, each bird in group 3 received each week an additional $20 \mathrm{mg} \alpha$-tocopheryl acetate emulsified in the drinking water. After 12 weeks (admittedly an arbitrary time, since signs of vitamin $E$ deficiency do not seem to have been described in the pigeon) the basal diet was changed to $\mathrm{PD}_{2}$, which was deficient in $\alpha$-tocopherol and Se, and the birds, still divided into the groups with and without dietary supplements, were transferred to this diet. After 2 weeks the birds were killed by breaking their necks, and tissues were taken for analysis as in the turkey experiment. No deficiency signs were observed in any of the pigeons before death. Post mortem, the livers of birds in all the groups showed dark patches, perhaps due to the high yeast content of the diet.

\section{RESULTS}

The analytical results are given in Tables 1,2 and 3 .

Tocopherol. In both experiments the birds maintained on the vitamin E-deficient diets contained barely significant quantities of tocopherol in the tissues examined, but the turkey poults showed clinical signs of deficiency, whereas the pigeons did not. This was perhaps due to the fact that the latter were adult birds, and vitamin E-deficiency signs are more often seen in young animals; perhaps the time scale of the pigeon experiment was not the best that could have been chosen. When the young turkeys were fed on the tocopherol-supplemented diet, little tocopherol appeared in either breast or thigh muscle, but a considerable quantity was found in the heart. In the pigeon, however, when the supplemented diet was given, an extraordinary increase took place in the tocopherol content of breast muscle. This increase is doubly remarkable: first, it was entirely unlike any effect we have previously encountered in the

Table x. Mean values for concentration of tocopherol, ubiquinone and ubichromenol in tissues of turkey poults on diets with and without vitamin $E$ and selenium

\begin{tabular}{|c|c|c|c|c|c|}
\hline Treatment & $\begin{array}{l}\text { Mean wt. } \\
\text { of survivors* } \\
\text { (g) }\end{array}$ & 'Tissue & $\begin{array}{l}\text { Ubiquinone } \\
\qquad(\mu \mathrm{g} / \mathrm{g})\end{array}$ & $\begin{array}{l}\text { Ubichromenol } \\
\qquad(\mu \mathrm{g} / \mathrm{g})\end{array}$ & $\begin{array}{c}\alpha \text {-Tocopherol } \\
(\mu \mathrm{g} / \mathrm{g})\end{array}$ \\
\hline Control & $590(6)$ & $\begin{array}{l}\text { Heart } \\
\text { Liver } \\
\text { Breast muscle } \\
\text { Thigh muscle }\end{array}$ & $\begin{array}{l}73 \\
32 \\
11 \\
18\end{array}$ & $\begin{array}{l}9 \\
4 \\
0 \cdot 6 \\
1\end{array}$ & $\begin{array}{l}1 \\
I \\
0.6 \\
0.1\end{array}$ \\
\hline + Tocopherol & $696(8)$ & $\begin{array}{l}\text { Heart } \\
\text { Liver } \\
\text { Breast muscle } \\
\text { Thigh muscle }\end{array}$ & $\begin{array}{r}106 \\
27 \\
18 \\
27\end{array}$ & $\begin{array}{r}12 \\
4 \\
1 \\
2\end{array}$ & $\begin{array}{r}10 \\
12 \\
2 \\
2\end{array}$ \\
\hline$+\mathrm{Se}$ & $660(8)$ & $\begin{array}{l}\text { Heart } \\
\text { Liver } \\
\text { Breast muscle } \\
\text { Thigh muscle }\end{array}$ & $\begin{array}{r}102 \\
55 \\
20 \\
16\end{array}$ & $\begin{array}{l}9 \\
6 \\
0.8 \\
I\end{array}$ & $\begin{array}{l}2 \\
3 \\
0.6 \\
0.5\end{array}$ \\
\hline
\end{tabular}

* No. of survivors in parentheses. 
Table 2. Mean values for concentration of ubiquinone and tocopherol in three adult turkeys on a stock ration

\begin{tabular}{lcc}
\multicolumn{1}{c}{ Tissue } & $\begin{array}{c}\text { Ubiquinone } \\
(\mu \mathrm{g} / \mathrm{g})\end{array}$ & $\begin{array}{c}\alpha-\text { Tocopherol } \\
(\mu \mathrm{g} / \mathrm{g})\end{array}$ \\
Heart & $\mathbf{1 3}$ & $\mathbf{1} \cdot 6$ \\
Liver & 37 & 3.9 \\
Ovary (immature) & 10 & $\mathbf{1 2 . 7}$
\end{tabular}

Table 3. Mean values for concentration of tocopherol, ubiquinone and ubichromenol in tissues of pigeons on diets with and without vitamin $E$ and selenium

\begin{tabular}{|c|c|c|c|c|c|}
\hline Treatment & $\begin{array}{l}\text { Mean wt. } \\
\text { of survivors* } \\
\text { (g) }\end{array}$ & Tissue & $\begin{array}{l}\text { Ubiquinone } \\
\qquad(\mu \mathrm{g} / \mathrm{g})\end{array}$ & $\begin{array}{l}\text { Ubichromenol } \\
(\mu \mathrm{g} / \mathrm{g})\end{array}$ & $\begin{array}{c}\alpha-\text {-Tocopherol } \\
(\mu \mathrm{g} / \mathrm{g})\end{array}$ \\
\hline Control (six birds) & 377 & $\begin{array}{l}\text { Heart } \\
\text { Liver } \\
\text { Breast muscle } \\
\text { Thigh muscle }\end{array}$ & $\begin{array}{r}178 \\
24 \\
174 \\
56\end{array}$ & $\begin{array}{r}7 \\
2 \\
5 \\
11\end{array}$ & $\begin{array}{l}0.4 \\
0.4 \\
0.8 \\
0.1\end{array}$ \\
\hline $\begin{array}{l}\text { Tocopherol, final dose } \\
\text { (five birds) }\end{array}$ & $3^{82}$ & $\begin{array}{l}\text { Heart } \\
\text { Liver } \\
\text { Breast muscle } \\
\text { Thigh muscle }\end{array}$ & $\begin{array}{r}165 \\
28 \\
249 \\
68\end{array}$ & $\begin{array}{r}\text { II } \\
\text { I } \\
6 \\
6\end{array}$ & $\begin{array}{r}4 \\
21 \\
2 \\
2\end{array}$ \\
\hline $\begin{array}{l}\text { Tocopherol in the diet } \\
\text { (seven birds) }\end{array}$ & $3^{83}$ & $\begin{array}{l}\text { Heart } \\
\text { Liver } \\
\text { Breast muscle } \\
\text { Thigh muscle }\end{array}$ & $\begin{array}{r}174 \\
31 \\
317 \\
56\end{array}$ & $\begin{array}{l}6 \\
3 \\
8 \\
8\end{array}$ & $\begin{array}{l}19 \\
58 \\
48 \\
10\end{array}$ \\
\hline $\begin{array}{l}\text { Se in the diet (seven } \\
\text { birds) }\end{array}$ & 400 & $\begin{array}{l}\text { Heart } \\
\text { Liver } \\
\text { Breast muscle } \\
\text { Thigh muscle }\end{array}$ & $\begin{array}{r}142 \\
38 \\
195 \\
55\end{array}$ & $\begin{array}{l}4 \\
2 \\
6 \\
7\end{array}$ & $\begin{array}{l}0.4 \\
3 \\
I \\
1\end{array}$ \\
\hline
\end{tabular}

muscles of other species and, secondly, there was a large difference between breast muscle and thigh muscle. It thus provides another excellent example of tissue specificity for tocopherol, previously discussed in connexion with the rabbit by Green et al. (I96I).

In the pigeon a single dose of tocopherol given orally $24 \mathrm{~h}$ before death produced a substantial increase in tocopherol concentration only in liver: in other tissues the increases were small (compare, for example, similar experiments in the rat by Diplock, Edwin, Bunyan \& Green, I96I). It can be observed that the tissues of vitamin-deficient animals given a supplement of Se nearly always contained more tocopherol than those of controls. We have already shown it to be so in the rat (Edwin, Bunyan, Diplock \& Green, r96r; Diplock et al. 196r), and it seems most probable that Se, besides its own biochemical role, has some slight sparing action on tocopherol. This is to be expected, since the biological roles of the two nutrients appear to be similar.

Ubiquinone. The natural ubiquinone in both species was shown chromatographically to be ubiquinone 50 . Tissues of birds fed on torula-yeast diets, however, contained substantial amounts of ubiquinones 35 and 45 , derived from the yeast. The three 
ubiquinones (and their isomeric chromenols) separated clearly on the two-dimensional chromatograms, and the figures recorded in the tables were obtained from the isolated ubiquinone 50 spots. The concentration of the exogenous ubiquinones was not measured: superficially, however, it was observed that ubiquinone 35 was chiefly concentrated in the liver.

Comparison of Tables $\mathrm{I}$ and 2 indicates a substantial difference between the concentration of ubiquinone in heart muscles of young and mature turkeys. Even though the 5-month-old birds were on an adequate diet, the ubiquinone concentrations in their hearts were only about a tenth of those for poults. The concentrations in liver did not exhibit such a difference.

The effect of tocopherol and Se on ubiquinone in the turkey. Ubiquinone concentrations in the tissues of the turkey poult were similar to those found in the rat. Although the design of these experiments does not allow of statistical analysis, it is likely (from results of similar experiments with rats) that in these experiments (with groups of six to eight birds) differences of about $20 \%$ found in the ubiquinone figures are real (Edwin, Diplock et al. 196r; Diplock et al. 1961). Both direction and magnitude of the effect of the two nutrients reinforce our earlier findings on the rat. The group given tocopherol contained higher ubiquinone concentrations in heart, breast and thigh muscle, but not in liver (liver is sometimes anomalous in the rat also); the group given Se contained higher concentrations in heart, liver and breast muscle, but not in thigh muscle. The high concentration of ubiquinone in liver parallels that observed in the rat after dietary supplementation with Se (Edwin, Diplock et al. 196r; Diplock et al. 1961).

The effect of tocopherol and Se on ubiquinone in the pigeon. Heart muscle contained a relatively high concentration of ubiquinone, which was not influenced by dietary supplementation. The concentrations of ubiquinone in both breast and thigh muscle were, in our experience, remarkable for this type of tissue. The concentration found in breast muscle was about ten times that found in the same muscles of rat and turkey and as much as 100 times that sometimes (but not always) found for the fowl (Bunyan et al. 1961). Once again, there was a manifest relationship between the high concentrations of tocopherol and ubiquinone in breast muscle; the figure of $3 \mathrm{I} 7 \mu \mathrm{g} / \mathrm{g}$ for the group given tocopherol is, we believe, the highest ubiquinone concentration so far recorded for any 'normal' tissue, only exceeded by that found in the hearts of certain rats dosed heavily with thyroxine (Edwin, Green, Diplock \& Bunyan, 1960). In contrast, dietary tocopherol did not affect the ubiquinone concentration in thigh muscle. Se did not appreciably increase the ubiquinone concentration in heart or in either of the two muscles; there was a considerable increase, however, in the concentration of ubiquinone in the liver of Se-treated animals (as there was in turkey liver).

Ubichromenol. The analytical results are given, but they do not seem to present any particular pattern. It appears, however, that the concentration of ubichromenol in avian tissues is lower than that found in the rat, especially in liver. 


\section{DISCUSSION}

The experiments suggest conclusions that confirm and amplify previous results on the rat. Thus the turkey experiment (and the results are also confirmed by those of similar experiments on the chicken, so far unpublished) suggests that the ubiquinone content of avian tissues may vary greatly with the age of the animal; this change, it must be emphasized, takes place independently of any dietary effects.

Secondly, in both the pigeon and turkey, it was possible to discern the same remarkable differences in the way the tissues take up tocopherol from the diet, as previously observed in the rat and the rabbit. The results indicate that dietary supplementation with either Se or tocopherol increased the ubiquinone concentration of several tissues in the growing turkey. In the adult pigeon, the breast muscle of birds fed on a tocopherol-supplemented diet contained exceptionally large amounts of tocopherol and ubiquinone, and it seems likely that these quantities are related to the high level of oxidation achieved by this tissue.

\section{SUMMARY}

I. Adult pigeons and turkey poults were reared on diets deficient in both selenium and tocopherol and compared with birds fed on diets supplemented with either one of these two nutrients. Four tissues from each species were analysed for ubiquinone, ubichromenol and $\alpha$-tocopherol.

2. Pronounced differences in the tissue concentrations of ubiquinone and tocopherol were found. When tocopherol was added to the deficient basal diets, there were substantial differences in the concentrations found in the various tissues.

3. The muscular tissues of turkeys given supplements of vitamin $E$ contained more ubiquinone than tissues from control animals. In the pigeon, tocopherol supplementation resulted in a remarkably high concentration of ubiquinone in breast muscle.

4. Animals given Se supplements contained substantially greater amounts of ubiquinone in their livers than did control animals.

\section{REFERENCES}

Bunyan, J., Edwin, E. E., Diplock, A. T. \& Green, J. (I96r). Nature, Lond., 19o, 637. Carter, C. W. \& O'Brien, J. R. (1937). Biochem. F. 3I, 2264.

Creech, B. G., Feldman, G. L., Ferguson, T. M., Reid, B. L. \& Couch, J. R. (1957). F. Nutr. 62, 83. Diplock, A. T., Edwin, E. E., Bunyan, J. \& Green, J. (I96I). Brit. F. Nutr. 15, 425. Diplock, A. T., Green, J., Edwin, E. E. \& Bunyan, J. (1960). Biochem. F. 76, 563. Edwin, E. E., Bunyan, J., Diplock, A. T. \& Green, J. (1961). Nature, Lond., r89, 747. Edwin, E. E., Diplock, A. T., Bunyan, J. \& Green, J. (1961). Biochem. F. 79, 91. Edwin, E. E., Green, J., Diplock, A. T. \& Bunyan, J. (1960). Nature, Lond., r86, 725. Green, J., Diplock, A. T., Bunyan, J. \& Edwin, E. E. (196r). Biochem. 7. 79, 108. Søndergaard, E., Bieri, J. G. \& Dam, H. (1960). Experientia, r6, 554. 